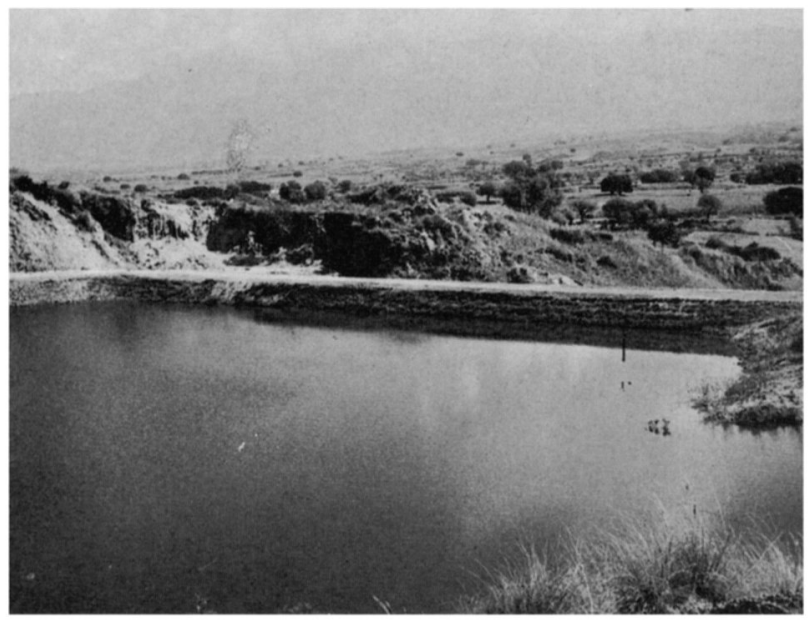

FIG. 2. One of the three Sukhomajri check-dams, showing in the background the green, cropped area below the dam.

provides the land, and they divide the crop equally with the larger farmer. Even the large landowners see that the coupon system is necessary to avoid the village tensions that would otherwise arise.

Employment opportunities have increased. The villagers have adopted rope-making as a cottage industry, using hemp. Due to the construction of the reservoirs, the microclimate of the area has changed, such that nurseries have sprung up in the village. Plants of several types, ranging from ornamentals to those producing fruits and vegetables,

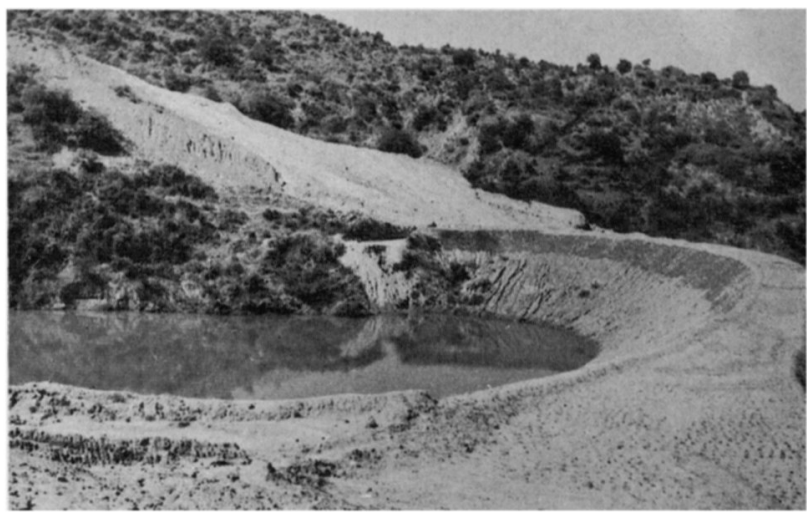

FIG. 3. Another Sukhomajri check-dam reservoir with, behind, a revegetated hill that at one time was practically barren.

are being grown to meet the requirements of nearby city folk-whereby the village is earning a revenue of some $\$ 6,000$ yearly by selling its nursery products.

In modern India, which loses some 6,000 million tonnes of topsoil each year, such efforts at the 'grass-roots level' can be vastly significant. It has now become widely believed that educating people can solve problems better than enforcing laws and regulations.

SUDHIRENDAR SHARMA
Centre for Policy Research
Dharma Marg
Chanakyapuri
New Delhi $110021 \quad$ India.

\title{
New Report Links World Debt Repayment to Environmental Damage
}

In a recent report a group of environmentalists, leaders from the international financial community, and academics, cautioned that hard-won population and environmental protection advances in the Third World may be threatened by the stringent conditions that are being imposed by the International Monetary Fund in forcing basic structural adjustments in an attempt to resolve the debt crisis. Those structural adjustments are actually accelerating negative environmental trends and limiting the long-term economic development potential of many countries, thus undermining the very purpose of the population control and environmental protection programmes. Some measures, such as eliminating food subsidies for city dwellers, are quite specific; but governments still have some latitude in the way they implement reform, and the report urges that they balance their options very carefully.

The report highlights the fact that contributions of forests, soil, and water, to healthy ecosystems, are not typically included in standard economic accounting, but tend to be undervalued in the course of negotiating readjustment policies.

A potential conflict exists between the short-term measures that are taken to tighten spending and are generally favoured by the private banks, and long-term programmes that are designed to slow deforestation, desertification, pollution, and population expansion. Right now, the report states, 'In some countries, urgently-needed potable water projects are being put off because every penny of foreign exchange is going for debt repayment.' If critical social and environmental programmes are deferred until economic recovery takes hold, natural resource deterioration may have accelerated beyond a country's ability to recover!

This dilemma thrusts the World Bank and the other public lenders into a key role, as, in the absence of private- bank lending, governments must turn to them. They, in turn, are compelled to take a long-term view of economic development and must also consider social and environmental programmes in their loan policy.

The report also states that, 'From an investment perspective, the stakes for long-term environmental stewardship are very high for large corporations and investors, since costs associated with unintended downstream environmental impacts could significantly reduce the ability of the operating company to meet debt repayments.'

The report is the third from a series of seminars initiated in 1983 as part of the Tufts University Talloires Program on International Environmental Issues, which explores interdisciplinary approaches to those critical problems. In addition to the seminars, Tufts University is emphasizing this interdisciplinary approach within its curricula. The recent seminar was co-sponsored by Tufts University and the International Earthcare Center, with funding from the EXXON Education Foundation, the United Nations Fund for Population Activities, and elsewhere.

J. GARY TAYLOR

Scharlin-Taylor Associates, Inc.

P.O.Box 1042

Lenox Hill Station

New York

NY 10021, USA,

\&

ROBERT M. HOLLISTER

Associate Professor and Chairman

Department of Urban \& Environmental Policy

Tufts University

Medford

Massachusetts 02155, USA. 